\title{
Analisis Fisika-Kimia Perairan dan Komunitas Bakteri terkait Kemunculan Penyakit Ice-ice pada Rumput laut (Kappaphycus alvarezii)
}

\author{
${ }^{1}$ Siska Ayu Wulandari, ${ }^{2}$ Isdiantoni, ${ }^{3}$ Endry Nurgoho Prasetyo \\ ${ }^{1}$ Prodi Pendidikan IPA, FKIP, Universitas Islam Lamongan \\ ${ }^{2}$ Fakultas Biologi, Fakultas Matematika dan Sains, Institut Teknologi Sepuluh Nopember \\ Email Korespondensi:siskaayu@unisla.ac.id., antonie.isd@yahoo.co.id,endry@bio,its.ac.id
}

\author{
Article Info \\ Article History \\ Received: 31 August 2020 \\ Revised: 20 September \\ 2020 \\ Published: 25 September \\ 2020 \\ Keywords \\ Kappaphycusalvarezii, ice- \\ ice, stratification.
}

\section{Informasi Artikel \\ Sejarah Artikel}

Diterima: 31 Agustus 2020

Direvisi: 20 September 2020

Dipublikasi: 25 September 2020

Kata kunci

Kappaphycus alvarezii, penyakit ice-ice, stratifikasi

\begin{abstract}
Ice ice disease can attacks the seaweed group of karaginofit especially Kappaphycusalvarezii which affects discoloration on tallus, decreases carragenan quality, and makes the production of seaweed is low. Thus, ice ice disease must be controled by prevention method to increase the yield quality through detection and identification of this disease. The aims of this research to explore the ice ice causedbacteria diversity in K. alvarezii based on the depth-stratification in order to determine the best depth of seaweed cultivation to avoid ice ice infection. Isolationof the bacteria from K.alvarezii cultivation area carried with terraced dilutionand spread method. The data will be analyzed descriptively. The result of this research was known that the bacteria caused ice-ice disease was found in depth 20 meter. This bacteria had caragenase activity and selulase enzyme to attack K. Alvarezzi thallus.
\end{abstract}

\begin{abstract}
Abstrak
Penyakit ice-ice merupakan penyakit yang menyerang rumput laut golongan karaginofit terutama Kappaphycus alvarezii. Penyakit ini menyebabkan penurunan produksi rumput laut dengan menurunkan kualitas karaginan. Oleh karena itu, penanggulangan penyakit ice-ice perlu dilakukan untuk meningkatkan kualitas rumput laut melalui deteksi dan identifikasi bakteri terkait penyakit ice-ice pada kedalaman berbeda sehingga dapat ditentukan kedalaman terbaik budidaya rumput laut dalam menghindari infeksi penyakit ice-ice. Isolasi bakteri dari perairan K. alvarezii dilakukan dengan metode pengenceran bertingkat dan metode sebar. Data isolat bakteri penyebab ice-ice yang didapatkan dianalisis secara deskriptif. Berdasarkan hasil penelitian diketahui bahwa komunitas bakteri direct attack teridentifikasi dari genus Bacillus dan Vibro terdistribusi pada kedalaman $20 \mathrm{~cm}$. Bakteri direct attack mampu melakukan aktifitas karaginase dan menghasilkan selulase untuk menyerang thallus K.alvarezii, maka penanaman K. alvarezii dapat dilakukan pada kedalaman lebih dari $20 \mathrm{~cm}$ untuk menghindari dampak yang lebih besar dari penyakit ice-ice.
\end{abstract}

Sitasi: Wulandari, Siska Ayu, Isdiantoni, \& Prasetyo, E. N. (2020). Analisis Fisika-Kimia Perairan dan Komunitas Bakteri terkait Kemunculan Penyakit Ice-ice pada Rumput laut (Kappaphycus alvarezii). Science Education and Application Journal. 2(2). 66-78

\section{PENDAHULUAN}

Kappaphycus alvarezii merupakan rumput laut dengan kandungan karaginan tinggi yang dapat dimanfaatkan sebagai sumber bahan baku industri pangan yaitu pengental, pembentuk gel, dan penstabil makanan [1, 2, 3, 4, 5]. Oleh karena itu di perairan Indonesia, K. alvarezii menjadi salah satu rumput laut favorit yang banyak dibudidayakan [6, 7, 8]. Walaupun demikian produksi $K$. alvarezii di perairan Indonesia masih terganggu oleh penyakit ice-ice yang mengakibatkan penurunan kualitas karaginan bahkan menyebabkan kegagalan panen [9, 10].

Penyakit ice-ice ditandai dengan timbulnya bintik atau bercak-bercak merah pada sebagian thallus yang lama kelamaan menjadi kuning pucat dan pada akhirnya menjadi putih serta 
lembek karena nekrosis $[11,12,13]$. Penyakit ice-ice diawali oleh faktor abiotik dan biotik lingkungan yang tidak menguntungkan (suhu, salinitas, intensitas cahaya dan populasi mikroba yang ekstrim) [14]. Kondisi tersebut mengakibatkan rumput laut menjadi tercekam (stress) yang berdampak menurunkan sistem kekebalan tubuh sehingga lebih rentan terhadap serangan patogen oportunistik $[13,15]$.

Pembudidayaan K. alvarezii di Desa Palasa Kabupaten Sumenep umumnya berada pada kedalaman $20 \mathrm{~cm}$ dari permukaan karena pada posisi tersebut penetrasi cahaya untuk fotosintesis rumput laut berlangsung optimal, tetapi sebaliknya kondisi tersebut merupakan kondisi optimum pertumbuhan mikroba penyebab penyakit ice-ice $[16,17]$.

Salah satu strategi tradisional pembudidaya rumput laut di Desa Palasa dalam mengatasi penyakit ice-ice adalah dengan menumbuhkan rumput laut pada strata kedalaman lebih dari 20 $\mathrm{cm}$ [18]. Teknik tersebut merupakan cara yang cukup efisien untuk mencegah terjadinya infeksi penyakit ice-ice walaupun tidak bisa dijadikan metode efektif untuk penyembuhan rumput laut yang sudah terkena penyakit ice-ice [19]. Meskipun telah di lakukan penanaman pada kedalaman yang berbeda, namun produksi $K$. alvarezii di Desa Palasa masih tergolong rendah apabila di bandingkan dengan beberapa Desa di Sumenep. Kondisi ini merupakan salah satu faktor dari budaya masyarakat sekitar yang masih buang air besar di perairan laut, sehingga perlu dilakukan uji MPN (Most Probable Number) untuk mendeteksi keberadaan bakteri kolifom di perairan.

Studi mengenai analisis fisika-kimia perairan dan komunitas bakteri terkait penyakit iceice pada kedalaman yang berbeda di area budidaya rumput laut belum banyak dilaporkan, sehingga dalam penelitian ini dilakukan eksplorasi keragaman bakteri terkait penyakit ice-ice berdasarkan stratifikasi perbedaan kedalaman perairan. Informasi yang diperoleh dalam penelitian dapat dijadikan acuan untuk menentukan kedalaman yang tepat dalam budidaya rumput laut sekaligus menghindari infeksi penyakit ice-ice.

\section{METODE}

\section{A. Waktu dan Tempat Penelitian}

Penelitian ini dilaksanakan selama 5 bulan dari Desember 2015-April 2016. Tempat pengambilan sampel air di area pembudidayaan $K$. alvarezii bertempat di Desa Palasa, Sumenep, Jawa Timur, sementara pengolahan serta analisis data dilakukan di Laboratorium Mikrobiologi dan Bioteknologi Jurusan Biologi Institut Teknologi Sepuluh Nopember, Surabaya..

\section{B. Metode yang Digunakan}

\section{Pengambilan Sampel Air di Lokasi Budidaya}

Pengambilan sampel air dilakukan dengan cara pengambilan bertingkat (pada kedalaman yang telah ditentukan yaitu $20 \mathrm{~cm}, 50 \mathrm{~cm}, 1 \mathrm{~m}$, dan $5 \mathrm{~m}$ di bawah permukaan air laut) dengan menggunakan La mote water sampler. Sampel air yang terambil kemudian dimasukkan kedalam botol kaca yang telah disterilisasi menggunakan alkohol $70 \%$ kemudian langsung ditutup dengan tutupnya, selanjutnya sampel air dalam botol kaca disimpan dalam coolbox. Sampel air yang diperoleh kemudian dibawa ke laboratorium untuk dianalisa jenis bakteri yang berada pada tiap stratifikasi dan dilakukan uji keberadaan bakteri koliform dengan metode MPN seri 3 tabung. 


\section{Parameter fisika dan kimia perairan}

Data parameter fisika dan kimia perairan diambil untuk menunjang penelitian. Parameter fisika dan kimia perairan yang diukur mencakup suhu, $\mathrm{pH}$, kecepatan arus, dan salinitas.

\section{Isolasi dan karakterisasi bakteri}

Sampel air diambil $1 \mathrm{~mL}$ kemudian dihomogenkan dalam $9 \mathrm{~mL}$ akuades steril. Tahap ini merupakan pengenceran 10-1. Tabung pengenceran berseri kemudian disiapkan hingga 1:1000 untuk masing-masing sampel kemudian sebanyak $0,1 \mathrm{~mL}$ diinokulasikan dengan metode sebar (spread plate) pada medium padat Alkaline Peptone Agar (APA) yang dilarutkan dalam air laut (30 \%o) [20]. Jumlah koloni yang tumbuh pada suhu ruangan setelah inkubasi 24-48 jam kemudian dihitung dalam satuan colony forming units (CFU). Koloni bakteri yang tumbuh selanjutnya diseleksi berdasarkan perbedaan karakter koloni dan pigmentasi yang beragam. Koloni bakteri hasil seleksi kemudian dimurnikan dan dikarakterisasi. Karakterisasi bakteri yang dilakukan terdiri atas: morfologi dan pigmentasi koloni, morfologi sel bakteri, uji Gram, pewarnaan endospora, uji katalase dengan hidrogen peroksida (H2O2) 3\%, uji oksidase dengan larutan tetra-metil-p-fenilenediamin dihidroklorida, kebutuhan oksigen dengan medium broth thioglikolat, fermentasi karbohidrat (glukosa, xilosa, mannose), dan Triple Sugar Iron Agar (TSIA).

\section{HASIL DAN PEMBAHASAN}

\section{a. Parameter Fisika-Kimia Perairan Desa Palasa}

Analisis kondisi fisik dan kimiawi dalam penelitian ini dilakukan untuk mengetahui keberadaan bakteri patogen akuatik dan memperkuat kesimpulan mengenai kondisi dan status lingkungan di perairan Palasa, Pulau Poteran, Kabupaten Sumenep. Hasil dari pengukuran parameter Fisika-Kimia perairan Desa Palasa dapat di lihat pada Tabel 3.1.

Tabel 3.1 Parameter Fisika dan Kimia Perairan Budidaya Rumput Laut di Desa Palasa

\begin{tabular}{lccccc}
\hline \multicolumn{1}{c}{$\begin{array}{l}\text { Parameter } \\
\text { Kimia }\end{array}$} & Fisika- & \multicolumn{2}{c}{$\begin{array}{l}\text { Rata-rata } \\
\text { pengukuran } \\
\text { Bulan }\end{array}$} & $\begin{array}{r}\text { Hasil } \\
\text { per }\end{array}$ \\
\hline Suhu $\left({ }^{0} \mathrm{C}\right)$ & Jan & Feb & Mar & Apr \\
\hline pH & 29 & 29 & 30 & 31,75 & 30,5 \\
\hline Salinitas $(\%)$ & 7,9 & 7,8 & 8 & 8 & 8 \\
\hline $\begin{array}{l}\text { Kecepatan } \\
(\mathrm{cm} / \mathrm{s})\end{array}$ & 32 & 32 & 33 & 34 & 34 \\
\hline Curah Hujan $(\mathrm{mm})$ & 18 & 8,7 & 18 & 8,3 & 14,2 \\
\hline
\end{tabular}

Pada Tabel 3.1 tampak bahwa kondisi lingkungan perairan di Desa Palasa sebenarnya cukup baik untuk pertumbuhan rumput laut yaitu suhu air laut berkisar $27-30^{\circ} \mathrm{C}$, pH 6,5-8,5, serta salinitas 30-37\%o, tetapi pada pada saat pengabilam sampel tidak satupun pembudidaya rumput 
laut yang menanam $[52,53,54,55]$. Hal ini dimungkinkan karena kecepatan arus laut yang jauh dari normal yaitu sebesar 8,3-18 cm/s. Menurut [56], kecepatan arus yang normal untuk pertumbuhan rumput laut adalah $20-40 \mathrm{~cm} / \mathrm{s}$. Arus laut yang lambat dapat menurunkan sirkulasi nutrisi sehingga menurunkan daya tahan rumput laut, akibatnya rumput laut menjadi mudah diserang patogen yang merupakan pemicu utama penyakit ice-ice [13].

\section{B. Komunitas Bakteri pada Kedalaman Berbeda}

Stratifikasi komunitas bakteri terkait penyakit Ice-ice pada rumput laut $K$. alvarezii diperoleh dengan cara isolasi dan identifikasi bakteri air laut pada kedalaman yang berbeda. Hasil identifikasi bakteri air laut pada kedalaman yang berbeda tercantum pada Tabel 3.2.

Tabel 3.2 Hasil Identifikasi Bakteri Air Laut pada Kedalaman Berbeda

\begin{tabular}{|c|c|c|c|c|c|}
\hline \multirow[t]{2}{*}{ KA } & \multicolumn{5}{|c|}{ Bulan } \\
\hline & Desember & Januari & Februari & Maret & April \\
\hline \multirow[t]{6}{*}{$20 \mathrm{~cm}$} & Flavobacterium & Flavobacterium & Flavobacterium & Flavobacterium & Flavobacterium \\
\hline & Kurthia & Kurthia & Kurthia & Kurthia & Kurthia \\
\hline & & & Vibrio & Vibrio & Vibrio \\
\hline & Bacillus & Bacillus & & & \\
\hline & & & & Pseudomonas & Pseudomonas \\
\hline & & & Micrococcus & & \\
\hline \multirow[t]{5}{*}{$50 \mathrm{~cm}$} & & & Flavobacterium & Flavobacterium & \\
\hline & Kurthia & Kurthia & & Kurthia & Kurthia \\
\hline & Klebsiella & Klebsiella & Klebsiella & & \\
\hline & & & Pseudomonas & Pseudomonas & \\
\hline & Micrococcus & Micrococcus & & Micrococcus & Micrococcus \\
\hline \multirow[t]{6}{*}{$1 \mathrm{~m}$} & & & & & \\
\hline & Kurthia & & & & Kurthia \\
\hline & & Lampropedia & & Lampropedia & \\
\hline & & & Klebsiella & & Klebsiella \\
\hline & & & Pseudomonas & & \\
\hline & Micrococcus & Micrococcus & Microcoсcus & Micrococcus & Micrococcus \\
\hline \multirow[t]{3}{*}{$5 \mathrm{~m}$} & TT & & Kurthia & & \\
\hline & & Klebsiella & Klebsiella & Klebsiella & Klebsiella \\
\hline & & Micrococcus & & Micrococcus & Micrococcus \\
\hline
\end{tabular}

$$
\begin{aligned}
\text { Keterangan }: & \mathrm{KA}=\text { Kedalaman Air } \\
\mathrm{TT} & =\text { Tidak Terukur }
\end{aligned}
$$

Pada Tabel 3.2 dapat dilihat bahwa komposisi bakteri yang teridentifikasi tiap bulannya adalah hampir sama. Hal ini menunjukkan bahwa tidak terdapat perbedaan keragaman bakteri di perairan laut desa Palasa dari bulan Desember sampai April karena masih dalam musim yang sama yaitu penghujan sehingga memiliki rentang suhu, $\mathrm{pH}$, salinitas, dan intensitas cahaya matahari yang sama [21, 22, 23, 24].

Hasil identifikasi berdasarkan tingkat kedalaman pada Tabel 3.2 menunjukkan bahwa Micrococcus teridentifikasi pada semua sampel air di setiap kedalaman. Micrococcus yang teridentifikasi dapat dimungkinkan karena merupakan bakteri halotoleran yang umum ditemukan pada habitat bersalinitas luas [25]. Di perairan, bakteri Micrococcus ini merupakan salah satu jenis patogen oportunistik bagi organisme yang mengalami imunosupresi [26, 27].

Kurthia juga teridentifikasi hampir di semua sampel air laut setelah Micrococcus. Kurthia dapat ditemukan di feses dan juga materi organik yang [28, 25]. Umumnya Kurthia adalah bakteri non-patogen terhadap manusia, tetapi beberapa spesies memiliki sifat patogen 
oportunistik [29, 30]. Keberadaan bakteri Kurthia pada kedalaman sampel air yang teridentifikasi dapat dimungkinkan berkaitan dengan keadaan lingkungan perairan Desa Palasa yang dimana masyarakat disana masih membuang air besar di laut.

Klebsiella teridentifikai pada kedalaman lebih dari $50 \mathrm{~cm}$, bakteri ini merupakan salah satu bakteri perairan laut yang bersifat non-motil yang menginfeksi berbagai hewan laut sebagai patogen oportunistik seperti ikan dan kerang [31]. Sedangkan, Flavobacterium, Bacillus dan Vibrio cenderung hanya ditemukan pada kedalaman $20 \mathrm{~cm}$ pada semua sampel di setiap bulannya. Ketiga bakteri ini memiliki diversitas yang luas dengan kemampuan adaptasi fisiologis terhadap perubahan lingkungan ekstrim dan tumbuh optimum pada suhu $30^{\circ} \mathrm{C}$ [25], sehingga dapat dimungkinkan kebaradaannya di kedalaman $20 \mathrm{~cm}$ karena faktor suhu permukaan perairan yang lebih tinggi yang merupakan suhu optimum untuk pertumbuhan.

Stratifikasi bakteri pada penelitian ini menunjukkan adanya tingkat keragaman yang berbeda di setiap kedalaman, semakin besar tingkat kedalaman maka semakin kecil tingkat keragaman bakteri yang teridentifikasi. Hal ini sesuai dengan yang dikemukakan oleh [32] bahwa bakteri dengan jenis beragam hidup pada permukaan perairan dan berkurang keragamannya seiiring dengan bertambahnya ingkat kedalaman.

Semua bakteri yang berhasil diidentifikasi adalah kelompok bakteri kemoorganotrofik yang mendapatkan sumber energi dan sumber karbon dari senyawa organik [33]. Salah satu bakteri kemoorganotrofik yang berhasil diidentifikasi adalah Bacillus yang merupakan bakteri gram positif berbentuk batang dan Flavobacterium dengan bentuk rod-shape gram negatif yang dapat dilihat pada Gambar 3.1. Selain itu beberapa bakteri yang teridentifikasi merupakan bakteri heterotropik yang memiliki peran ekologis penting di perairan laut sebagai dekomposer yang menguraikan material organik menjadi komponen yang lebih sederhana sebagai unsur hara yang esensial seperti Pseudomonas [34].
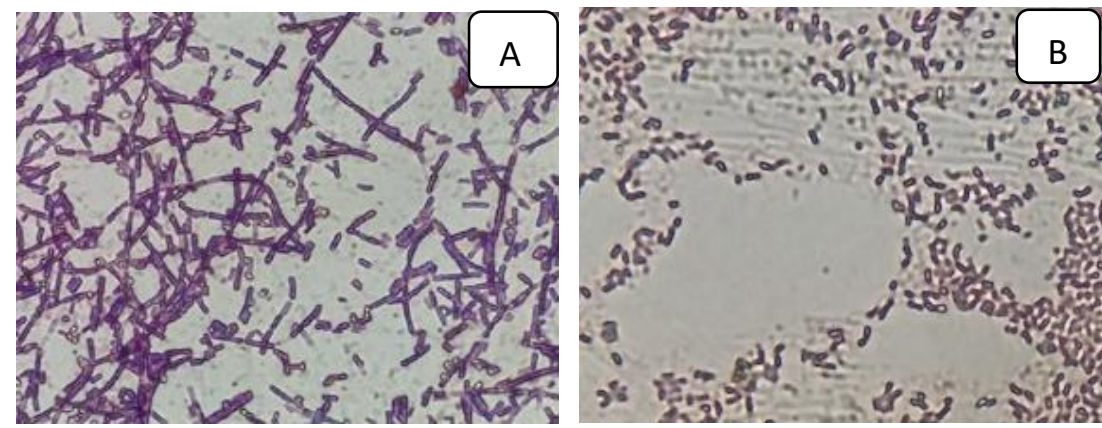

Gambar 3.1 Dokumentasi Bakteri Hasil identifikasi (A) Bacillus, (B) Vibrio dengan perbesaran $1000 \mathrm{x}$

\section{Kelimpahan Bakteri pada Kedalaman Berbeda}

Gambar 3.2 menunjukkan data Total Plate Count (TPC) pada setiap kedalaman sampel air di perairan Desa Palasa pada bulan Desember 2015 -April 2016. 


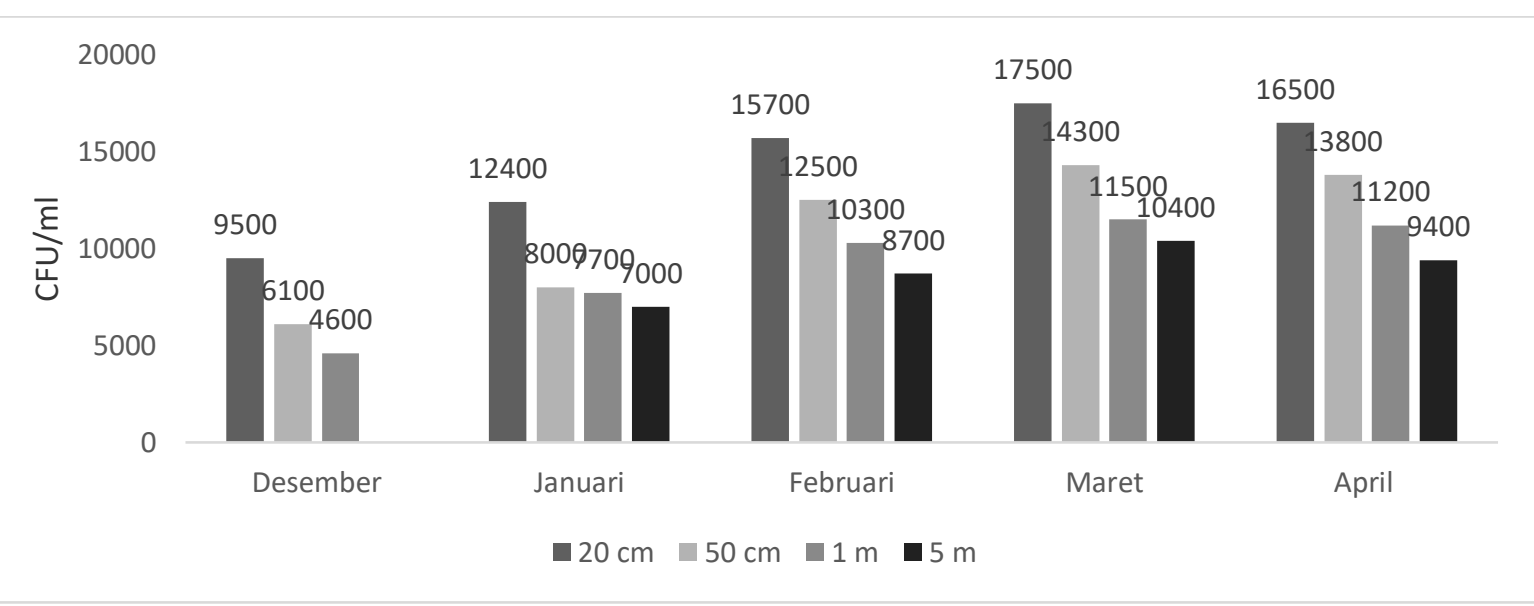

Gambar 3.2 Grafik Total Plate Count pada setiap Kedalaman di Perairan Laut Desa Palasa

Total kelimpahan bakteri berdasarkan nilai CFU yang terhitung pada perairan laut di Desa Palasa antara bulan Desember 2015 - April 2016 ternyata cukup tinggi yaitu sekitar $(0,46$ 1,75)x $10^{4} \mathrm{CFU} / \mathrm{ml}$. Hal ini dapat menunjukkan bahwa di perairan laut Desa Palasa mengandung banyak senyawa organik dan lingkungan yang sesuai untuk pertumbuhan mikroorganisme. Bahan Organik sendiri merupakan salah satu bahan yang dibutuhkan oleh mikroorganisme untuk pertumbuhan dan perkembangannya, sehingga dengan tingginya kadar bahan organik akan meningkatkan pertumbuhan bakteri di perairan laut [35, 36, 37].

Kelimpahan bakteri tertinggi di perairan Palasa terdapat pada kedalaman $20 \mathrm{~cm}$ disetiap bulannya dan berkurang seiiring dengan bertambahnya kedalaman. [38] menyatakan bahwa bakteri lebih melimpah di permukaan perairan dan jumlahnya akan menurun pada tingkat kedalaman yang semakin besar. Kelimpahan bakteri pada kedalaman $20 \mathrm{~cm}$ diduga berkaitan dengan arus permukaan laut sebagai tempat terakumulasinya bahan organik yang membawa material organik dalam jumlah besar masuk ke dalam perairan Palasa sehingga berdampak pada kelimpahan bakteri yang tinggi [39]. [40] menambahkan bahwa kandungan bakteri erat kaitannya dengan suplai dan distribusi nutrisi di dalam ekosistem perairan laut sehingga menunjukkan pengaruh daratan terhadap kandungan bakteri sangat signifikan. Selain itu kelimpahan bakteri pada perairan dipengaruhi oleh fluktuasi konsentrasi bahan organik berupa senyawa kimia dari mikrobia lainnya seperti fitoplankton dan zooplankton, serta paparan sinar matahari juga menentukan distribusi vertikal bakteri dalam suatu perairan [41].

Kelimpahan bakteri tertinggi didapat pada bulan Maret. Hal ini diduga karena pada bulan Maret merupakan musim penghujan dengan curah hujan tinggi sehingga perairan Palasa mendapat pengaruh run off dari daratan akibat hujan yang terjadi di Palasa dan sekitarnya. Keadaan perairan Palasa pada bulan Maret dimungkinkan menerima limpasan material organik dari daratan ke perairan laut akibat hujan menjadikan kelimpahan bakteri lebih banyak dibandingkan bulan-bulan sebelumnya.

\section{Tingkat Kedalaman dan Kemungkinan Kemunculan Penyakit Ice-ice}

Kondisi lingkungan perairan desa palasa yang menjadi faktor abiotik yang ikut mempengaruhi bakteri dan mempengaruhi budidaya rumput laut. Gambar 3.3 menunjukkan data Most Probable Number (MPN) pada kedalaman yang berbeda . 


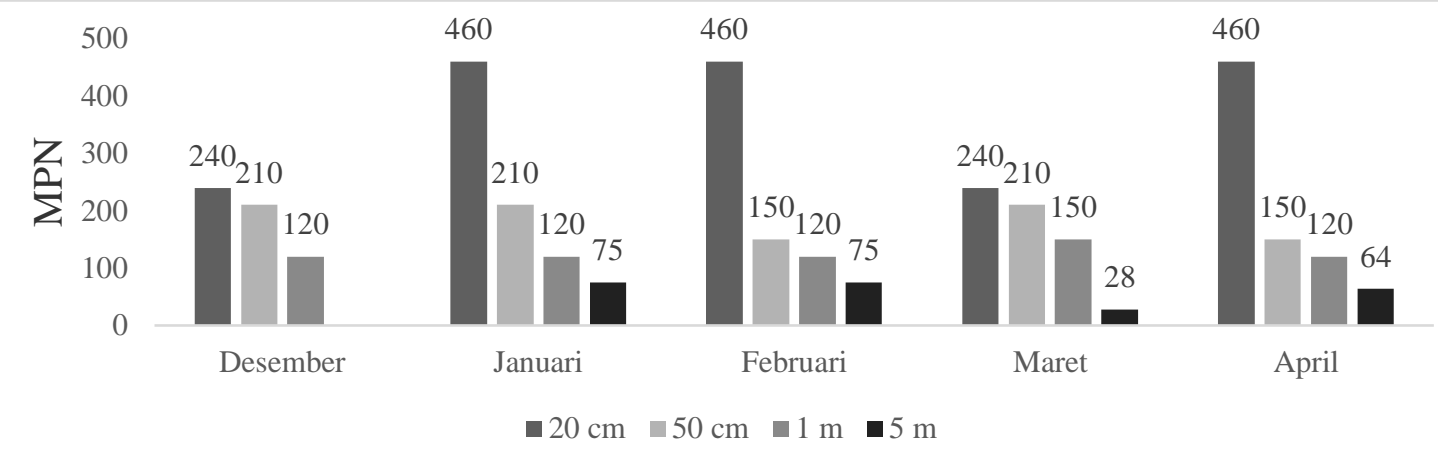

Gambar 3.3 Grafik Most Probable Number (MPN) pada setiap Kedalaman di Perairan Laut Desa Palasa

Keberadaan patogen sebagai faktor biotik pemicu utama penyakit ice-ice diketahui melalui analisis MPN untuk mendeteksi adanya bakteri koliform. Walaupun bakteri koliform secara umum tidak patogen, keberadaan bakteri koliform dapat menjadi indikator adanya bakteri patogen lain dalam air laut [42]. Hasil analisis data MPN pada Gambar 3.3 berkisar antara 28$460 \mathrm{MPN} / 100 \mathrm{~mL}$ berdasarkan tabel MPN tiga seri tabung [43]. Angka tersebut berada di bawah baku mutu kadar maksimum total koliform yang diperbolehkan ada di perairan laut untuk budidaya yakni $700 \mathrm{MPN} / 100 \mathrm{~mL}$, sehingga kemungkinan adanya patogen hampir tidak ada [44]. Walaupun demikian, mikroorganisme penyebab penyakit ice-ice dapat tetap menyerang rumput laut dalam kondisi mengalami imunosupresi akibat stress lingkungan, karena sifat bakteri penyebab ice-ice adalah patogen oportunistik [45, 46, 47].

Keberadaan bakteri coliform lebih banyak ditemukan pada bulan januari, Februari dan April, hal ini diduga karena kegiatan penduduk pada bulan tersebut tinggi, sehingga logis jika akumulasi dan kelimpahan bakteri ini lebih banyak, karena sumber utama dari bakteri ini berasal dari limbah rumah tangga [48]. Kondisi arus permukaan dan curah hujan yang kecil $[49,50]$ yang membawa massa air diduga turut berpengaruh terhadap sebaran bakteri coliform ini [51].

Berdasarkan grafik MPN diketahui bahwa pada bulan Maret nilai MPN rendah namun pada kelimpahan bakteri berdasarkan nilai CFU yang ditunjukkan oleh Gambar 3.2 memiliki nilai yang cukup tinggi, hal ini dapat dimungkinkan karena titik sampling, kecepatan arus dan curah hujan akan mempengaruhi sebaran bakteri coliform pada nilai MPN dan nilai CFU yang didapatkan karena pada suatu titik yang berbeda akan menunjukkan hasil MPN dan CFU yang berbeda pula. Arus yang cukup besar akan mempengaruhi fluktuasi limbah maupun berbagai kotoran sehingga akan menurunkan nilai MPN yang didapatkan. Colony Forming Unit digunakan untuk menghitung bakteri secara keseluruhan tidak termasuk bakteri patogen di dalam air melalui indikator keberadaan koliform berdasarkan mpn yang diperoleh.

Bakteri terkait penyakit ice-ice dapat diklasifikasikan menjadi dua yaitu serangan langsung dan serangan tidak langsung [57], [58]. Pada Gambar 3.4 dapat dilihat stratifikasi komunitas bakteri yang dikelompokkan berdasarkan bakteri serangan langsung dan tidak langsung. 


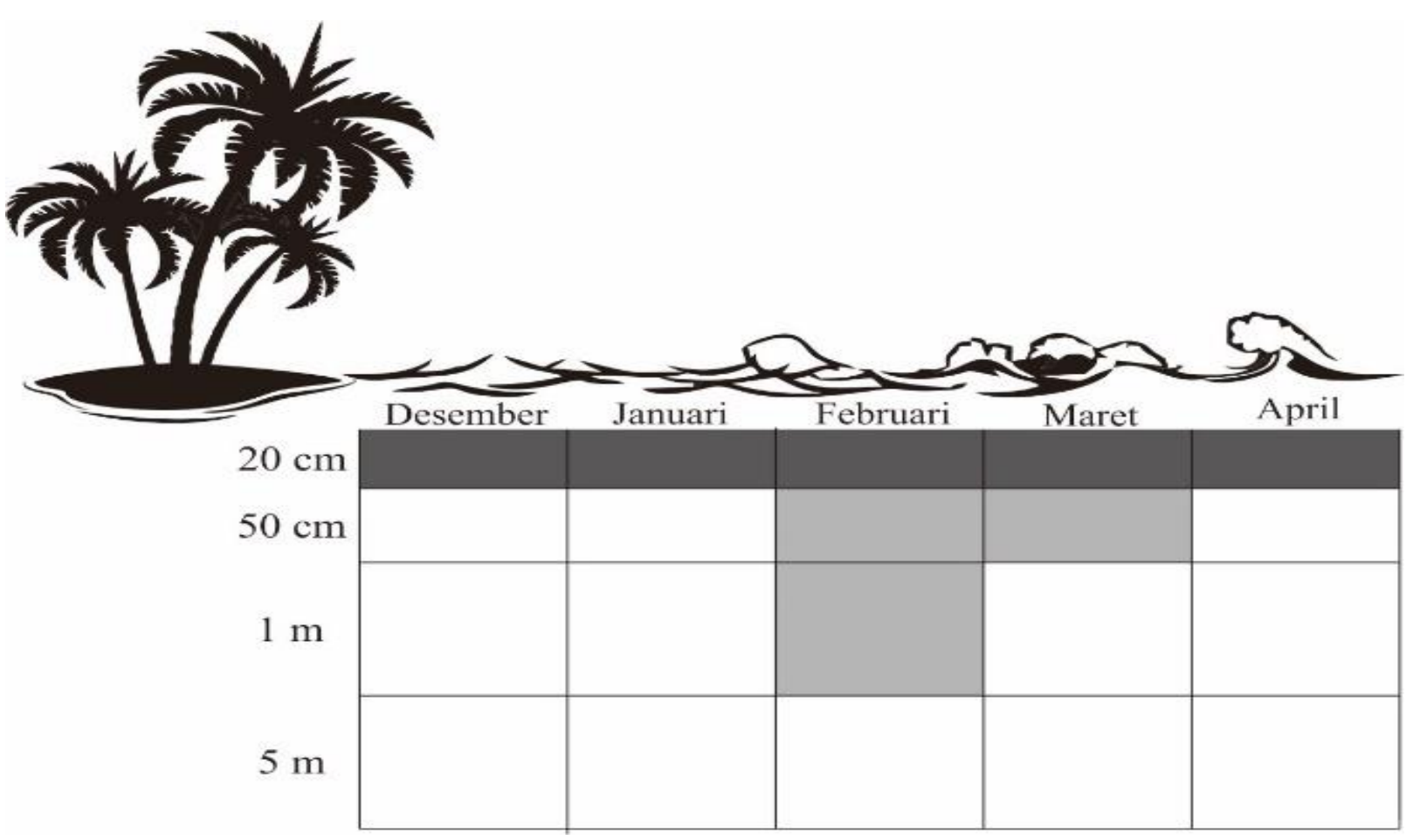

Keterangan :

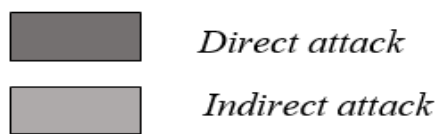

Pada Gambar 3.4 dapat dilihat bahwa bakteri direct attack terdistribusi pada strata paling atas permukaan air laut, bakteri ini terdiri dari genus Bacillus dan Vibrio yang merupakan bakteri aerob dan fakultatif an-aerob yang mampu tumbuh dengan keberadaan oksigen serta kebanyakan hidup optimum pada suhu $30^{\circ} \mathrm{C}$ atau lebih, kedua bakteri ini teridentifikasi pada kedalaman $20 \mathrm{~cm}$ yang memiliki suhu permukaan lebih tinggi apabila yang merupakan suhu optimum untuk pertumbuhan [25]. Direct attack bacteria umumnya memiliki kemampuan untuk menghidrolisis karaginan [13] yang selanjutnya bermultiplikasi sebagai awal infeksi penyakit ice-ice [59].

Bakteri indirect attack teridentifikasi pada kedalaman $20 \mathrm{~cm}, 50 \mathrm{~cm}$, dan $1 \mathrm{~m}$ berasal dari genus Flavobacterium dan Pseudomonas. Bakteri indirect attack yang teridentifikasi ini merupakan bakteri aerob serta dapat tumbuh pada suhu $25-30^{\circ} \mathrm{C}$, sehingga dapat ditemukan pada permukaan maupun dibawah kolom perairan yang memiliki perbedaan suhu [25]. Indirect attack bacteria disebabkan oleh bakteri patogen opurtunistik yang menempel pada thallus K.alvarezii apabila tercekam oleh kondisi lingkungan [24].

Pada kedalaman $20 \mathrm{~cm}$ serangan penyakit ice-ice akan terjadi lebih besar bila dibandingkankan dengan kedalaman yang lain. Hal ini disebabkan karena pada kedalaman 20 cm ditempati oleh komunitas bakteri direct attack yang mampu melakukan serangan langsung terhadap talus rumput laut. Dengan demikian, disarankan penanaman rumput laut $K$. alvarezii dilakukan pada kedalaman lebih dari $20 \mathrm{~cm}$ untuk menghindari dampak yang lebih besar dari penyakit ice-ice. 


\section{KESIMPULAN}

Analisis fisika-kimia perairan dan komunitas bakteri terkait kemunculan penyakit ice-ice pada rumput laut (Kapaphycus alvarezii) dalam penelitian ini dapat disimpulkan bahwa:

1. Komunitas bakteri pada kedalaman berbeda yang teridentifikasi tiap bulannya memiliki komposisi yang hampir sama.

2. Total kelimpahan bakteri berdasarkan nilai CFU antara bulan Desember 2015 - April 2016 cukup tinggi yaitu sekitar $(0,46-1,75) \times 10^{4} \mathrm{CFU} / \mathrm{ml}$.

3. Kondisi lingkungan perairan di Desa Palasa cukup baik untuk pertumbuhan $K$. alvarezii, namun kecepatan arus laut Desa Palasa jauh dari normal yaitu sebesar 8,3-18 cm/s.

4. Penanaman rumput laut $K$. alvarezii dapat dilakukan pada kedalaman lebih dari $20 \mathrm{~cm}$ untuk menghindari dampak yang lebih besar dari penyakit ice-ice.

\section{SARAN}

Dari penelitian mengenai analisis fisika-kimia perairan dan komunitas bakteri terkait kemunculan penyakit Ice-ice pada rumput laut (Kappaphycus alvarezii) penanggulangan terhadap penyakit ice-ice pada $K$. alvarezii diharapkan dapat ditemukan selain dengan cara penanaman $\quad K$. alvarezii pada kedalaman $50 \mathrm{~cm}$. Salah satu cara yang mungkin bisa dilakukan adalah dengan:

1. Karakterisasi isolat secara genotipik untuk mengetahui kekerabatan isolat yang didapatkan sehingga dapat ditemukan antibakteri yang mampu menghambat pertumbuhan bakteri terkait penyakit ice-ice.

2. Penyisipan gen rumput laut spesies berbeda yang tahan terhadap lingkungan ekstrim dengan cara kultur jaringan K.alvarezii di Palasa dengan parameter fisika-kimia yang disesuaikan pada skala laboratorium agar mendapatkan rumput laut K.alvarezii yang tahan terhadap kondisi lingkungan yang berubah-ubah.

\section{UCAPAN TERIMA KASIH}

Penulis S.A mengucapkan terima kasih kepada Bapak Dr. tech. Endry Nugroho Prasetyo M.T., Bapak Isdiantoni, S. P., M. P., Ibu N.D. Kuswytasari S.Si., M. Si., dan Bapak Farid Kamal Muzaki S.Si., M.Si. atas masukan dan arahannya dalam penyelesain artikel penelitian ini. Terima kasih juga ditujukan kepada Bapak Adwi, penduduk lokal Desa Palasa, pulau Poteran, Sumenep, Madura, atas bantuannya. Tidak lupa penulis mengucapkan terima kasih kepada teman-teman angkatan 2012 Biologi ITS dan kelompok peneliti Biomaterial and Enzyme Technology Research Team atas bantuan, dukungan, dan doa dalam penyelesaian penelitian.

\section{DAFTAR PUSTAKA}

[1]S. Mustapha, H. Chandar, Z. Z. Abidin, R. Saghravani dan M. Y. Haru, "Production of semirefined carrageenan from Eucheuma cottonii," in Journal of Scientific \& Industrial Research. Vol. 70 (2011) 865-870..

[2]F. Van de Velde, S. H. Knutsen, A. I. Usov, H. S. Romella, and A. S. Cerezo, "1H and 13 C high resolution NMR spectoscopy of carrageenans: aplication in research and industry," in Trend in Food Science and Technology. Vol. 13 (2002) 73-92.

[3] V. L. Campo, D.F. Kawano, D. B. Silva Júnior, I. Ivone Carvalho, "Carrageenans: biological properties, chemical modifications and structural analysis," in Carbohydrate Polymers. Vol. 77 (2009) 167180. 
[4] I. Neish, C. "The ABC of Eucheuma Seaplant Production. Agronomy, Biology and Crophandling of Betaphycus, Eucheuma and Kappaphycus the Gelatine, Spinosum and Cottonii of Commerce". SuriaLink Monograph. (2003).

[5] N. G. Hurtado. Guanzon, Jr. T. R. de Castro-Mallare, dan M. R. J. Luhan (Eds). "Recent development in seaweed disease". Proceedings of the National Seaweed Planning Workshop. Tigbauan, ilolo: SEAFDEC Aquaculture Department (2000).

[6] Kementerian Kelautan dan Perikanan. (2014, 23 November). Kepala Pusat Pelatihan Kelautan dan Perikanan Buka Pelatihan Budidaya Rumput Laut di Kabupaten Minahasa Selatan.

[7] Prasetyowati, C. Jasmine, dan D. Agustiawan, "Pembuatan tepung karaginan dari rumput laut (Eucheuma cottonii) berdasarkan perbedaan metode pengendapan," dalam Jurnal Teknik Kimia. Vol. 2 (2008) 2733.

[8] Sahabuddin dan Tangko, A.M. "Pertumbuhan dan Mutu Kadar Karaginan Rumput Laut Eucheuma cotonii Pada Substrat Dasar Yang Berbeda di Perairan Bantaeng Sulawesi Selatan. Balai Riset Perikanan Budidaya Air Payau Maros". Seminar Nasional Tahunan V Hasil Penelitian Perikanan Dan Kelautan (2008).

[9] M.K. Tokan. "Morphology Characteistics of Microorganisme of the Seaweed (Eucheuma spinosum) Suffering of The Ice-Ice Disease". Journal Biotropical Sains. No. 2.Vol. 3 (2009): $18-25$.

[10] W. G. Mendoza, N. E. Montano, E. T. Ganzon-Fortes, R. D. Villanu Eva, "Chemical and Gelling Profile of ice-ice Infected Carageenan from Kappaphycus striatum (Schmitz) Doty "Sacol" Strain Solieciriciae, Gigartinales, Rhodophyta)," in Journal of Applied Phycology. Vol. 14 (2002) 409-418.

[11] T. W. Aditya dan Ruslan. "Rekayasa Teknologi Produksi Rumput Laut (Kappaphycus alvarezii)”. Laporan Tahunan Balai Budidaya Laut Tahun Anggaran (2003).95-97 p.

[12] M. Fresco, C. O. "Ice-ice" algae pose threat on Zamboanga's seaweeds. Bureau of Agricultural Research. (2012).

[13] D. B. Largo, "Recent development in seaweed disease". In A. Q. Hurtado, N. G. Guanzon, Jr. T. R. de Castro-Mallare, dan M. R. J. Luhan (Eds). Proceedings of the National Seaweed Planning Workshop. (2000). Tigbauan, ilolo: SEAFDEC Aquaculture Department.

[14] D. B. Largo, K. Fukami, T. Nishijima and M. Ohno, "Laboratoryinduced development of the ice-ice disease of the farmed red algae Kappaphycus alvarezii and Eucheuma denticulatum (Solieriaceae, Gigartinales, Rhodophyta)," in Journal of Applied Phycology. Vol. 7 (1995a) 539-543.

[15] W. L. Tisera dan R. A. Naguit. "Ice-ice disease occurrence in seaweed farms in Bais Bay, Negros Oriental and Zamboanga del Norte". The Treshold. Volume 4 (2009).

[16] K. Kordi, M. Ghufran. "Pengelolaan Kualitas Air dalam Budidaya Perairan”. Jakarta: PT Rineka Cipta. (2004).

[17] D.P. Praseno dan Sugestiningsih. Retaid di Perairan Indonesia. Pusat Penelitian Oseanografi LIPI. Jakarta. 82hlm (2000).

[18] S. Djai. "Pengaruh Jarak Tanam Yang Berbeda Terhadap Pertumbuhan dan Kadar Karagenan Rumput Laut Varietas Hijau Kappaphycus alvarezii dengan Menggunakan Metode Long Line di Desa Toli-Toli Kecamatan lalonggasumeeto Kabupaten Konawe”. Skripsi Fakultas Perikanan dan Imu Kelautan Universitas Haluoleo Kendari. 50 hall (2010). 
[19] K. Yulianto, dan Mira. S. "Budidaya Makroalga K. alvarezii (Doty) Secara Vertikal Dengan Gejala Penyakit Ice-Ice Diperairan Pulau Pari. UPT". Loka Pengembangan Kompetensi SDM Oseanografi Pulau Pari-LIPI. 334 hal. (2009).

[20] R. M. Atlas, Handbook of Media for Environmental Microbiology, 2nd Ed. USA: Taylor and Francis Group, LLC (2005).

[21] L.C. Xia. "Extended local similarity analysis (eLSA) of microbial community and other time series data with replicates". BMC Syst. Biol. 5 (Suppl. 2), S15 (2011).

[22] A. A. Lie, Y., Kim, D. Y., Schnetzer, A. \& Caron, D. A. "Small-scale temporal and spatial variations in protistan community composition at the San Pedro Ocean Time-series station off the coast of southern California”. Aquat. Microb. Ecol. 70, 93-110 (2013).

[23] M. Sapp, Wichels, A., Wiltshire, K. H. \& Gerdts, G. "Bacterial community dynamics during the winterspring transition in the North Sea". FEMS Microbiol. Ecol. 59, 622-637 (2007).

[24] D. L. Kirchman, Williams, P. J. le B.. Introduction. pp, 1-11. In: Kirchman, D. L. (Ed), "Microbial Ecology of the Oceans", Wiley-Liss, Inc, New York. (2000).

[25] R. S. Breed, E.G.D. Murray dan A.P. Hitchens (eds). "Bergey's Manual of Determinative Bacteriology, 6th ed”. The Williams and Wilkins Co., Baltimore. pp. 545-59 . (1957).

[26] T. L. Bannerman, \& Peacock, S. J. "Staphylococcus, Micrococcus, and Other CatalasePositive Cocci”. In P. R. Murray, E. J. Baron, J. H. Jorgensen, M. L. Landry \& M. A. Pfaller (Eds.), Manual of Clinical Microbiology (9th ed., pp. 390404). Washington, USA: ASM Press. (2007).

[27] M. Kocur, Kloos, W. E., \& Schleifer, K. H. “The Genus Micrococcus”. In M. Dworkin, S. Falkow, E. Rosenberg, K. H. (2006).

[28] P. G. Hauduroy, Ehringer, A. Urbain, G. Guillot, and J. Magrou. "Dictionnaire des bacteries pathogenes". Masson et Cie, Paris. pp. 1-597; Moore, W.E.C. and L.V. Holdeman. 1970 in Cato, E.P., C.S. Cummins, L.V. Holdeman, J.L, Johnson, W.E.C. Moore, R.M. Smibert and L.DS. Smith (eds). Outline of clinical methods in anaerobic bacteriology, 2nd revision. Virginia Polytechnic Institute Anaerobe Laboratory, Blacksburg, Virginia. (1937).

[29] J. G. Holt, N. R. Krieg, P. H. A. Sneathm, J. T. Staley, dan S. T. Williams. "Bergey's Manual of Systemic Bacteriology, Vol. I \& II". Baltimore, MD: Williams and Williams. (1986).

[30] P. R Murray., et al. "Manual of Clinical Microbiology, 6th ed". Washington, D.C: American Society for Microbiology. (1995).

[31] S. Bagley. "Habitat association of Klebsiella species". Infect Control. Vol. 6 (1985) (2): $52-8$.

[32] C. R. Mahon, D. C. Lehman, dan G. Manuselis.. "Textbook of diagnostic microbiology, 4th ed". W. B. Saunders Co., Philadelphia, PA. (2011).

[33] M. T. Madigan, J. M. Martinko, D. A. Stahl, dan D. P. Clark. "Brock Biology of Microorganisms". San Fransisco : Pearson Education, Inc. (2012).

[34] S. Aksornkoae. "Ecology and Management of Mangrove". IUCN, Bangkok, Thailand. (1993).

[35] A.M.G. Klein Tank, and KönnenG.P: "Trends in indices of daily temperature and precipitation extremes in Europe", 1946-99. Journal of Climate, 16 ., (2003), 3665-3680.

[36] M. W. Denny, dan S. D. Gaines. "Encyclopedia of Tidepools and Rocky Shores". California: University of California Press, Ltd. (2007).

[37] R. Hadioetomo, S. "Mikrobiologi Dasar Dalam Praktek : Teknik dan Prosedur Dasar Laboratorium”. PT Gramedia Pustaka Utama. Jakarta. (1993). 
[38] M. H. Azkab. "Struktur dan Fungsi Pada Komunitas Lamun". Oseana 25 (3) (2000): 9-17 [39] R, Dahuri, Rais J, Ginting SP, Sitepu MJ. "Pengelolaan Sumber Daya Wilayah Pesisir dan Lautan Secara Terpadu. Jakarta (ID)": Pradnya Paramita. (1996).

[40] D. H. Kunarso,. "Peranan Bakteri Heterotrofik Dalam Ekosistem Laut". Jurnal Oseana. XIII(4) (1988): 133-142.

[41] T. Taguchi, and T. Platt. "Size distribution and chemical composition of particulate matter in Bedford Basin, 1973 and 1974. Fisheries \& Marine Service Data Report No. 56, Canadian" Department of Fisheries \& Environment, p 1-370. (1978).

[42] World Health Organization, Guidelines for Drinking-Water Quality. Geneva (1997).

[43] J. L. Oblinger and J. A. Koburger, "Understanding and Teaching the Most Probable Number Technique," in J. Milk Food Technol. Vol. 38 (1975): 540-545.

[44] Peraturan Gubernur Daerah Istimewa Yogyakarta, Baku Mutu Air Laut. (2010) No. 3.

[45] M. T. Parker, Hospital-acquired infections: guidelines to laboratory methods. Copenhagen: World Health Organization Regional Office for Europe (European Series, No. 4) (1978).

[46] Largo, D. B., K. Fukami and T. Nishijima, "Occasional pathogenic bacteria promoting ice-ice disease in the carrageenan producing red algae Kappaphycus alvarezii and Eucheuma denticulatum (Solieriaceae, Gigartinales, Rhodophyta)," in Journal of Applied Phycology. Vol. 7 (1995b) 545-554.

[47] S. Egan, N. D. Fernandes, V. Kumar, M. Gardiner and T. Thomas, "Bacterial pathogens, virulence mechanism and host defense in marine macroalgae," in Environmental Microbiology. Vol. 16 (2014): 925-938.

[48] I. Karliana. "Identifikasi mikroba air laut di Ujung Grenggengan Semenanjung Muria". Jurnal Sigma Epsion, 13(2) (2009), 59-63.

[49] E. R. Shofiyanti, \& Siswanto, A. D. "Arus permukaan dan konsentrasi total suspended solid di Selat Madura, Kabupaten Bangkalan, Madura”. Prosiding Seminar Nasional Hasil Penelitian Perikanan dan Kelautan, Fakultas Perikanan dan Ilmu Kelautan, Universitas Diponegoro, Semarang. (2013).

[50] A. D. Siswanto, \& Syah, A. F. "Karakteristik arus di perairan Selat Madura". Prosiding Seminar Nasional Hasil Penelitian Perikanan dan Kelautan, Fakultas Perikanan dan Ilmu Kelautan, Universitas Diponegoro, Semarang. (2013a).

[51] E. A. Wahyuni. "Studi karakteristik arus dan pengaruhnya terhadap sebaran bakteri Coliform di perairan Selat Madura". Prosiding Pertemuan Ilmiah Tahunan (PIT) Ikatan Sarjana Oseanologi Indonesia (ISOI), Balikpapan. (2014).

[52] D. Setiyanto, I. Efendi dan K. J. Antara. "Pertumbuhan Kappaphycus alvarezii var Maumare, var Sacol dan Eucheuma cottonii di perairan Musi Buleleng”. J. Ilmu Kelautan. 13 (3) (2008): 171176.

[53] L. M. Aslan, "Budidaya Rumput Laut”. Yogyakarta: Kanisius (2005).

[54] Samsuari, "Penelitian Pembuatan Karaginan dari Rumput Laut Eucheuma cottonii di Wilayah Perairan Kabupaten Jeneponto propinsi Sulawesi Selatan". Bogor: Institut Pertanian Bogor (2006).

[55] N. Soenardjo, Membudidayakan Rumput Laut. Semarang: Balai Pustaka Semarang (2003).

[56] Winarno, Teknik Pengolahan Rumput Laut. Jakarta: Pustaka Sinar Harapan (1996).

[57] D.B. Largo, Fukami K, Adachi M, Nishijima T. "Immunofluorescent detection of ice-ice Disease-Promoting Bacterial Strain Vibrio sp. P11of the Farmed Macro Alga, Kappaphycus 
alvarezii of Aquatic Environmental Science (LAQUES)”, Departement of Aquaculture, Faculty of Agriculture, Kochi University-Japan. (2003).

[58] K. Yulianto. "Pengamatan Penyakit Ice-ice dan Alga Kompetitor Fenomena Penyebab Kegagalan Panen Budidaya Rumput Laut (Kappaphycus alvarezii) di Pulau Pari, Kepulauan Seribu". Prosiding Seminar Riptek Kelautan Nasional. Pusat Penelitian Oceanografi-LIPI. Jakarta. (2002).

[59] G.A. Santos. "Carrageenan of species of Eucheuma J. Agardh and Kappaphycus Doty (Solieriaceae, Rhodophyta)". Aquat. Bot. 36 (1989): 55-67. 